\title{
MODEL PENANGGULANGAN BANJIR
}

\section{Oleh: Dede Sugandi*)}

\section{ABSTRAK \\ Banjir dan genangan merupakan masalah tahunan dan memberikan}

pengaruh besar terhadap kondisi masyarakat baik secara social, ekonomi maupun lingkungan. Banjir bukan merupakan masalah pribadi yang diteliti berdasarkan disiplin ilmu, tetapi banjir diakibatkan system lingkungan yang rusak dan mata rantai fisis lingungan yang terganggu, sehingga untuk mengatasi masalah banjir perlu dikaji secara terpadu.

Banjir di wilayah Bandung Selatan, Jakarta Bekasi, Tangerang atau daerah lainnya disebabkan pada badan sungai terjadi pendangkalan oleh endapan material hasil erosi dari hulu sungai. Pendangkalan sungai tersebut menyebabkan kapasitas sungai berkurang. Selain terjadinya pendangkalan sungai, karena debit air yang mengalir dari hulu sungai meningkat. Peningkatan debit aliran pada anakdari hulu sungai sebagai akibat curah hujan yang turun tidak/kurang meresap ke dalam tanah, sehingga curah hujan menjadi aliran permukaan. Aliran permukaan yang bergerak di permukaan tanah mengikis tanah dan membawa ke badan sungai, karena itu aliran sungai bukan saja debit meningkat juga ditambah material hasil erosi. Material hasil erosi yang mengendap dengan debit aliran yang meningkat menyebabkan aliran air tidak dapat ditampung oleh sungai, sehingga aliran langsung pada badan sungai meluap yang berakibat banjir di sekitar dan sepanjang dataran sungai.

Debit air permukaan yang meningkat yang disebabkan curah hujan yang tidak meresap, maka salah satu usaha yang perlu dikembangkan adalah curah hujan yang jatuh ke permukaan tanah harus meresap. Dengan ketebalan curah hujan dengan debit aliran permukaan yang meningkat, maka setiap unit penggunaan lahan harus mampu meresapkan curah hujan yang jatuh pada setiap satuan lahan yang ada, sehingga aliran permukaan kecil yang dapat ditampung badan sungai. Banjir yang terjadi hanya di sekitar wilayah Bandung Selatan, Jakarta, Bekasi, Tangerang dan daerah lainnya, karena daerah tersebut merupakan daerah yang datar dan paling rendah. Tetapi Curah hujan yang terjadi di seluruh wilayah, terutama hulu sungai, maka untuk mengatasi peningkatan debit aliran permukaan, maka pada daerah hulu sungai dan penggunaan lahan perlu dikembangkan model resapan yang dapat menampung curah hujan meresap sebelum aliran permukaan mengalir melalui badan sungai.

Model yang perlu dikembangkan untuk mengatasi terjadinya banjir adalah dengan megurangi debit aliran permukaan, maka pada setiap unit penggunaan lahan harus meresapkan curah hujan. untuk mersapkan curah hujan dengan cara pembuatan sumur resapan alau lahan resapan. Pada setiap unit lahan aliran permukaan dialirkan pada sumur resapan atau aliran permukaan dialirkan ke lahan resapan, dimana struktur tanah pada lahan resapan diubah menjadi lahan yang mampu meresapkan air.

*) Drs. Dede Sugandi, M.Si., adalah dosen Jurusan Pendidikan Geografi FPIPS UPI. 


\section{Pendahuluan}

Kita sering mendengar berita, baik Media elektronik maupun bukan bahwa lingkungan kita sering terjadi masalah yang dihadapi, terutama pada saat mulai musim penghujan. Karena pada musim penghujan hujan sering terjadi hujan dengan intensitas tinggi yang menyebabkan bencana banjir dan longsor. Banjir biasanya terjadi di daerah dengan morfologi relative datar, sedangkan longsor terjadi pada daerah dengan morfologi perbukitan, bergelombang atau pada lereng pegunungan. Artinya bahwa banjir dan longsor terjadi pada kawasan tangkapan hujan yang disebut Daerah Aliran Sungai(DAS).

Banjir dan longsor pada suatu kawasan DAS menunjukan bahwa DAS merupakan suatu ekosistem yang mengalami kerusakan. Kerusakan ekosistem ini disebabkan karena factor pembentuk ekosistem terganggu. Asdak (2002) mengemukakan bahwa ekosistem merupakan suatu system ekologi yang terdiri atas komponen-komponen yang saling berintergrasi, sehingga membentuk suatu kesatuan. Dengan demikian dalam suatu ekosistem tidak ada satu komponenpun yang berdiri sendiri melainkan ia mempunyai keterkaitan dengan komponen lain, langsung atau tidak langsung, besar arau kecil. Sedangkan ekosistem DAS berhubungan dengan segala aspek yang ada dan diolah manusia dalam mempertahankan hidupnya, sehingga ekosistem tersebut sangat dipengaruhi manusia dalam mengolah lahan yang ada pada DAS tersebut. Arsyad (2000) mengemukakan bahwa Lahan disrtikan sebagai lingkungan fisik yang terdiri atas, iklim, relief, tanah, air dan vegetasi serta benda yang ada diatasnya sepanjang ada pengaruhnya terhadap penggunaan lahan. Pendapat tersebut menunjukan bahwa factor pembentuk ekosistem membentuk mata rantai yang saling berpengaruh, karena itu jika manusia dalam mengelola lahan kemungkinan besar akan berpengaruh terhadap ekosistem yang terbentuk, jika pengaruh dalam pengelolaan lahan pada DAS akan berpengaruh terhadap mata rantai tersebut, jika mata rantai tersebut terputus, maka yang muncul adalah bencana, seperti; banjir dan Longsor.

\section{Permasalahan}

Ekosistem DAS yang rusak menunjukan bahwa factor pembentuk ekosistem terganggu, sehinga terjadi masalah banjir dan longsor. Banjir merupakan masalah yang dihadapai warga setempat yang dihadapi setiap tahun dan tidak akan berakhir tanpa usaha dan kesadaran dari wilayah dan penduduk yang berpengaruh terhadap terjadinya masalah. Banjir bukan hanya merupaka masalah penduduk, tetapi berkaitan dengan keadaan lingkungan fisik yang rusak. Rusaknya lingkungan fisik akibat pengelolaan dan pemanfaatan wilayah sesuai dengan fungsinya.

Banjir berkaitan dengan curah hujan dan waktu merupakan fenomena alam yang agak sulit dikendalikan, tetapi pemanfaatan lahan merupakan fenomena alam yang dipengaruhi kegiatan manusia. Karena itu pemanfaatan lahan harus memperhatikan kaidah lingkungan, sehingga lingkungan fisik dapat memberikan hasil dan kenyamanan bagi penduduk untuk tinggal. Pemanfaatan lahan yang tidak sesuai akan memberikan dampak terhadap terjadinya masalah, karena perubahan pada wilayah secara fisik seolah-olah memutus mata rantai lingkungan yang sudah serasi. 
Di pihak lain manusia akan tumbuh dan berkembang dari tahun ke tahun. Perkembangan penduduk ini akan berkaitan dengan pemenuhan kebutuhan dasar manusia, seperti : Sandang ( Pakaian dan Perumahan), Pangan (makan dan minum) dan Papan (Pekerjaan). Dengan kebutuhan primer manusia ini timbul untuk memenuhi kebutuhan tersebut, dimana kebutuhan tersebut akan merubah fungsi lahan tanpa memperhatikan kondisi dan kaidah lingkungan.

Banjir yang terjadi setiap tahun ini tidak hanya dilakukan untuk menanggulangi sedimentasi di badan sungai, tetapi yang mendasari terjadinya banjir adalah kapasitas sungai tidak sesuai dengan debit air yang mengalir, sehinga aliran air meluap dari badan sungai. Luapan air sungai menyebabkan banjir dan longsor. Banjir yang terjadi disebabkan oleh berbagai factor yang saling berkaitan yang membentuk system lingkungan, karena ada beberapa factor factor lingkungan terganggu mempengaruhi system lingkungan. Terjadinya banjir dapat digambarkan sebagai berikut :

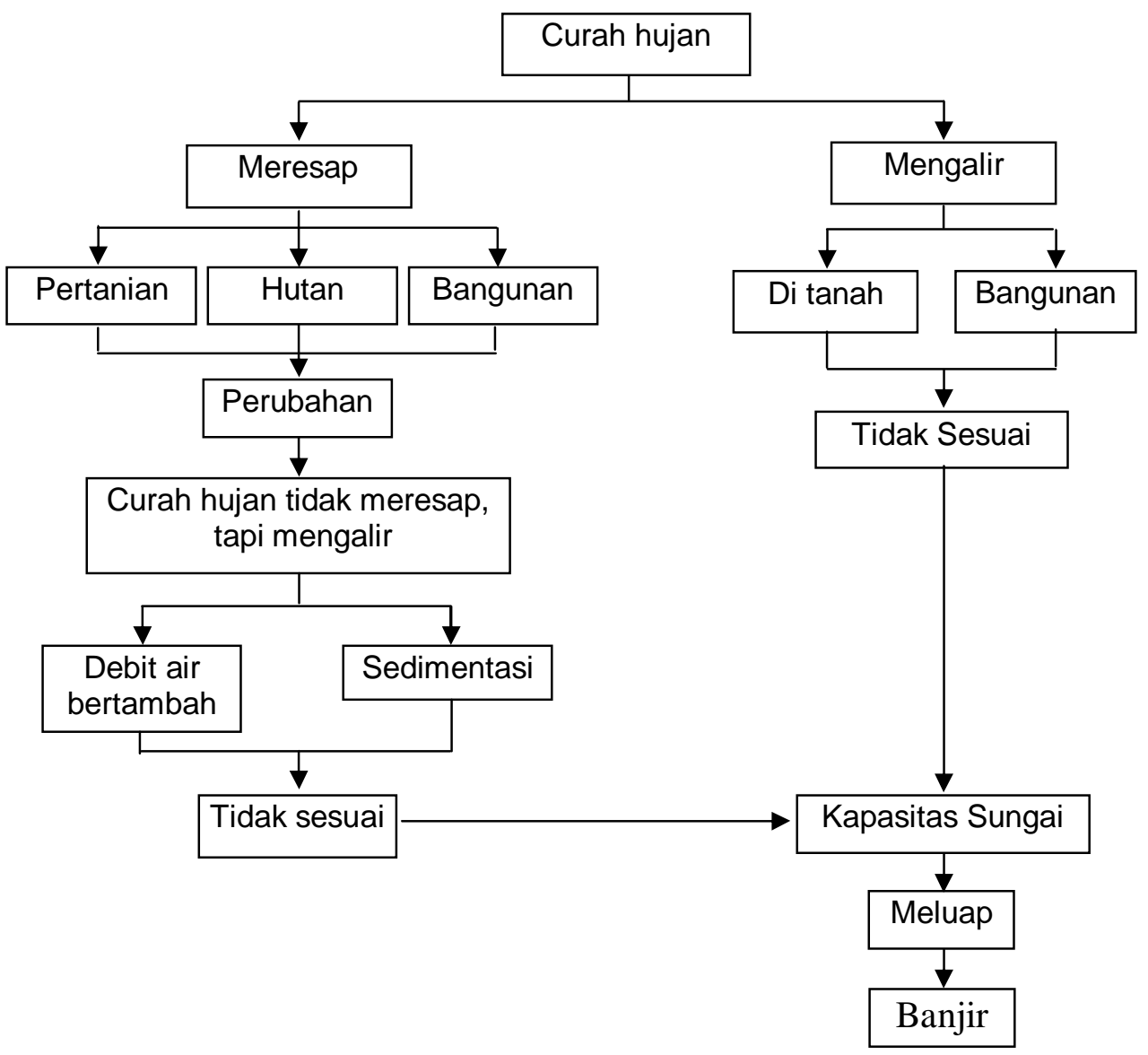

Gambar: Proses terjadinya banjir 
Sungai memiliki kemampuan untuk mengalirkan air baik langsung dari curah hujan maupun ditambah dengan air yang meresap dan keluar sebagai aliran ke sungai. Karena lahan berfungsi sebagai lahan yang mampu meresapkan air hujan, seperti hutan, lahan perkebunan, tetapi akibat kebutuhan manusia akan lahan, maka lahan hutan dan perkebunan mengalami perubahan baik dari hutan menjadi lahan pertanian dan pemukiman maupun lahan pertanian menjadi lahan pemukiman atau penggunaan yang lain. Perubahan penggunaan lahan ini mempengaruhi terhadap kemampuan lahan terhadap peresapan air, sehingga curah hujan peresapan berkurang menimbulkan aliran permukaan bertambah. Bertambahnya air di permukaan akhirnya akan mengalir ke sungai. Itu menunjukan bahwa sungai yang memiliki kapasitas aliran tertentu akan bertambah, sehingga kapasitas sungai tidak mampu untuk menampung debit aliran. Tidak sesuainya kapasitas dan debit aliran menyebabkan alirn sungai akan meluap dan menimbulkan banjir.

Aliran permukaan sebagai akibat lahan tidak meresapkan curah hujan akan membawa material hasil erosi yang bergerak bersama aliran permukaan dan akan terendapkan pada wilayah yang relative datar, karena itu pada badan sungai terjadi sedimentasi. Sedimentasi ini akan menurunkan kapasitas sungai untuk mengalirkan aliran sungai. Banjir yang terjadi disebabkan oleh berbagai factor, maka dalam penanggulangan banjir di Bandung Selatan diperlukan upaya yang tepat. Hal yang perlu dikembangkan adalah bagaimana curah hujan yang jatuh ke permukaan bumi tidak mengalir sebagai aliran permukaan, tetapi dapat menyerap ke dalam tanah.

\section{Kajian Pustaka}

\section{a. Aliran Permukaan}

Aliran permukaan merupakan gerakan air di permukaan tanah, akibat curah hujan yang jatuh ke tanah tidak dan kurang terserap oleh tanah. Aliran air ini membentuk alur pengaliran yang membentuk sungai. Artinya sungai yang terbentuk sesuai dengan debit aliran yang bergerak. Besar kecilnya debit Aliran permukaan sangat dipengaruhi oleh kondisi fisis lahan, seperti Relief/topografi, sifat tanah, batuan, bentuklahan dan penggunaan lahan.

Bransby and William mengemukakan bahwa aliran permukaan dipengaruhi oleh Intensitas hujan, Relief, Infiltrasi tanah, Penggunaan lahan dan storage. Sedangkan Cook mengemukakan bahwa aliran permukaan dipengaruhi oleh Relief, Infiltrasi tanah, Penggunaan lahan.

Relief yang mempengaruhi gerakan aliran permukaan adalah kecuraman lereng, karena semakin curam kemiringan lereng, akan semakin cepat gerakan air dn mempekecil terjadinya infiltrasi. Kemiringan lereng sifatnya stabil, sehingga kurang berpengaruh terhadap peningkatan debit aliran permukaan secara permanent, kecuali oleh pengelolaan lahan diatasnya. Arvin, $M(2004)$ mengemukakan bahwa semakin besar kemiringan lereng pada sebuah sungai semakin cepat gerakan aliran permukaan.

Sifat tanah yang mempengaruhi aliran permukaan, seperti tekstur, struktur, bahan organic tanah. Sifat tanah ini mempengaruhi terhadap kemampuan tanah untuk melakukan infiltrasi air di permukaan. Dede Sugandi(1992) mengemukakan semakin kasar dan besar kandungan BO tanah akan semakin besar kemampuan tanah untuk menginfiltrasi tanah. Sifat tanah tersebut menyediakan pori-pori anah 
yang besar, sehingga gerakan air pada pori-pori tanah memiliki kapasitas yang besar.

Tekstur tanah dan struktur sangat mempengaruhi terhadap besar kecilnya laju dan kapasitas infiltrasi, semakin kasar tekstur tanah, maka semakin besar kapasitas infilltrasi.

Tabel: Kapasitas Infiltrasi berbagai Macam Tanah dari Pengukuran Lapangan

\begin{tabular}{|c|l|c|}
\hline No & Macam Tanah & $\begin{array}{c}\text { Kapasitas Infiltrasi } \\
\mathrm{mm} / \mathrm{jam}\end{array}$ \\
\hline 1 & Pasir berlempung & $25-50$ \\
2 & Lempung & $12,5-25$ \\
3 & Lempung berdebu/Silt & $7,5-15$ \\
4 & Loam & $2,5-5$ \\
5 & Lempung berliat/Clay Loam & $<0,5$ \\
& Liat/Clay & \\
\hline
\end{tabular}

Sumber : Arsyad, 2000

Faktor lain yang sangat berpengaruh terhadap besarnya aliran permukaan adalah penggunaan lahan. Setiap penggunaan lahan sangat menentukan besarnya debit aliran. karena permukaan tanah yang tertutup oleh lapaisan kedap air, maka curah hujan yang jatuh ke permukaan tanah akan menjadi aliran permukaan. Sedangkan permukaan tanah yang ditumbuhi oleh tumbuhan berakar dalam akan mempengaruhi besarnya laju infiltrasi dan mengurangi debit aliran. Artinya untuk mengurangi debit aliran suatu daerah datau sualtu lahan bagaimana agar curah hujan yang jatuh ke permukaan tanah dapat menyerap.

Selain Penggunaan lahan factor yang mempengaruhi aliran permukaan adalah storage atau kemampuan lahan utnuk menyimpan air. Umumnya lahan yang dapat menyimpan aair adalah cekungan atau sungai. Sungai merupakan daerah yang lebih rendah dari daerah sekitarnya dan merupakan tempat bergeraknya air.

\section{b. Infiltrasi Tanah}

Infiltrasi tanah merupakan kemampuan tanah untuk menyerap air, semakin besar infiltrasi tanah, maka debit aliran permukaan tanah akan berkurang. Infiltrasi tanah berkaitan dengan tekstur dan struktur tanah serta kedalaman tanah. Tekstur tanah yang kasar akan meningkatkan laju infiltrasi tanah sedangkan kedalaman tanah akan meningkatkan kapasitas infiltrasi. Seyhan (1993) mengemukakan bahwa proses infiltrasi akan berpengaruh terhadap :

1) Berkurangnya banjir dan erosi tanah

2) Memberikan air bagi vegetasi

3) Mengisi kembali reservoir air

4) Menyediakan aliran pada sungai musiman

Sedangkan Dede Sugandi(1992) mengemukakan bahwa tekstur tanah yang kasar sangat berpengaruh untuk memperkecil aliran permukaan, karena curah hujan yag jatuh ke permukaan tanah akan terinfiltrasi ke dalam tanah. 


\section{Metode Penelitian}

Metode penelitian yang digunakan adalah eksperimen, karena metode ini cocok untuk menerapkan upaya untuk mengurangi debit aliran permukaan, karena debit aliran merupakan penyebab utama terjadinya banjir. Sedangkan wilayah yang menjadi sample kajian didasarkan pada mecam dan tekstur tanah, karena tekstur tanah menjadi factor utama untuk mengurangi debit aliran permukaan.

\section{Pembahasan}

Dari faktor-faktor yang berpengaruh terhadap aliran permukaan adalah Intensitas hujan, relief, infiltrasi tanah, penggunaan lahan dan storage. Jika diamati tiap faktor tersebut, maka ada faktor yang sifatnya tetap dan berubah, juga ada faktor yang tidak bias dirubahh dan dapat dirubah.

Intensitas hujan merupakan factor alami yang sulit untuk dirubah, kecuali dialakukan hujan buatan, meskipun demikian curah hujan yang turun sekarang besar mungkin nanti akan berkurang. Artinya curah hujan yang ada sangat dipengaruhi besar keilnya penguapan.

Relief merupakan ketinggian dan bentuk muka bumi, secara umum relief sulit diubah. Relief secara mikro mungkin dapat riubah, tetapi secara makro relief sifatnya tetap, sedangka aliran pemukaan bergerak di permukaan secara makro. Artinya bahwa gerakan air denga diubahnya relirf secara mikro, maka gerakan air di permukaan akan cepat dan kadang-kadang lambat.

Penggunaan lahan merupakan lahan yang dimanfaatkan untuk berbagai penggunaan oleh manusia. Untuk memenuhi kebutuhannya manusia mengubah lahan menjadi berbagai kegiatan seperti pertanian, hutan sekunder, sawah, perkebunan, pemukiman atau penggunaan yang lainnya. Lahan yang digunakan untuk hutan belukar memiliki kedalaman akar yang cukup, sehingga akan berpengaruh terhadap infiltrasi tanah. Semakin dalam akar vegetasi dan tanah semakin dalam kemampuan tanah untuk infiltrasi semakin besar. Lain halnya jika lahan digunakan oleh kegiatan yang dapat menghilangkan sifat tanah dalam menginfiltrasi air, seperti bangunan, aspal, maka lapisan tanah menjadi kedap air, sehingga air hujan yang turun ke permukaan tanah tidak akan terjadi infiltrasi dan akan menjadi aliran permukaan. Sedangkan aliran permukaan merupakan penyebab terjadinya banjir.

Infiltrasi tanah merupakan kemampuan tanah untuk meresapkan air hujan atau air yang mengalir diatasnya. Besar kecilnya infiltrasi dipengaruhi oleh tekstur, struktur, BO, kedalaman tanah. Sifat-sifat tanah tersebut dapat meningkatkan infiltrasi, semakin kasar, dalam dan besar kandungan $\mathrm{BO}$, maka infiltrasi semakin besar dan sebaliknya. Secara makro infiltrasi tanah sifatnya tetap, tetapi secara mikro sifat tanah dapat diubah. Artinya bahwa untuk mengurangi aliran permukaan, maka sepanjang aliran sungai, sifat tanah dapat diubah, sehingga curah hujan yang turun dapat terinfiltrasi dan mengurangi aliran permukaan.

Storage merupakan tempat penyimpanan air di permukaan tanah dapat berupa cekungan tanah maupun badan sungai. Secara alami badan sungai terbentuk karena adanya aliran air dan tersebntuk sesuai dengan kapasitasnya. Artinya secara makro timbunan air tetap, sedangkan secara mikro dapat diubah.

Dari factor-faktor yang menyebabkan terjadinya aliran permukaan, maka factor yang dapat diubah untuk menanggulangi aliran permukaan adalah Penggunaan lahan dan infiltrasi tanah. Penggunaan lahan sangat berkaitan 
dengan laju pembangunan dan perkembangan penduduk, karena itu lahan yang memiliki kemampuan untuk respan air sebaiknya dibiarkan menjadi daerah hijau dan pada pusat-pusat keramaian atau pemukiman sebaiknya terdapat lahan hijau sebagai lahan resapan air.

Selain penggunaan lahan, maka sifat-sifat tanah dapat diubah untuk meningkatkan kemampuan permukaan lahan untuk infiltrasi. Aliran permukaan terjadi jika ada curah hujan dan tidak menyerap ke dalam tanah. Dengan perubahan penggunaan lahan terutama oleh lapisan kedap air, seperti bangunan dan aspal maka aliran permukaan akan semakin besar, karena itu sifat tanah secara mikro perlu diubah dengan cara bahwa pada setiap bangunan harus ada lahan kosong dan sifat tanah seperti tektur dan struktur tanah diubah menjadi lebih kasar seperti berangkal atau sampah organic, sehingga lahan tersebut kemampuan untuk meresapkan air semakin besar. Cara lain pada setiap bangunan perlu sumur resapan, sehingga curah hujan yang turun dapat tertampung pada sumur resapan tersebut. Dengan kata lain bahwa pada setiap penggunaan lahan harus memiliki kemampuan untuk meresapkan air, sehingga curah hujan yang jatuh ke permukaan tidak menjadi aliran permukaan.

\section{Penutup}

Aliran permukaan merupakan proses alam yang dapat dipengaruhi manusia dalam memenuhi kebutuhannya, karena mata rantai dari ekosistem yang terganggu akan berpengaruh terhadap aliran permukaan. Faktor-faktor alam dari aliran permukaan sangat menentukan terjadinya banjir, jika salah satu factor terganggu.

Banjir disbabkan aliran permukaan meningkat, karena infiltrasi tanah menurun, maka usaha untuk mengurangi aliran permukaan dengan meningkatkan kemampuan tanah untuk meresapkan air hujan yang turun pada permukaan tanah. Upaya untuk meningkatkan infiltrasi tanah, maka curah hujan tidak sampai keluar sebagai aliran permukaan. Karena itu untuk meningkatkan infiltrasi tanah, maka pada setiap unit penggunaan lahan harus dilakukan upaya untuk meninglatkan infiltrasi tanah baik dengan sumur resapan atau lahan resapan dengan mengubah sifat-sifat tanah.

\section{Daftar Pustaka}

Agus Susanto. 2004. Studi Tingkat Bahaya Erosi di Sub Daerah Aliran Ci Meta Hulu Daerah Aliran Ci Tarum, Bandung: Geografi FPIPS UPI.

Anita, K.D. 2004. Studi Erosi pada Lahan Pertanian di Sub Daerah Aliran Ci Kendang Kabupaten Garut, Bandung: Geografi FPIPS UPI.

Arsyad, Sinatala. 2000. Konservasi Tanah dan Air, Bogor: IPB Press.

Arvin, Mulya. 2004. Pengaruh Perubahan Penggunaan Lahan Terhadap Kuantitas Aliran Permukaan di Daerah Aliran Ci Kapundung Hulu, Bandung: Geografi FPIPS UPI.

Dede Sugandi, 1992. Pemanfaatan Foto udara untuk menganalisis Perubahan Debit Aliran Permukaan di Daerah Aliran Ci Kapundung Bandung, Yogyakarta: Universitas Gadjah Mada.

Asdak, C. 2002. Hidrologi dan Pengelolaan Daerah Aliran Sungai, Yogyakarta: Gadjah Mada University Press. 
Seyhan, Ersin. 1990. Dasar-Dasar Hidrologi, Yogyakarta: Gadjah Mada University Press. 